Нада Савковић

821.163.41.09 Стефановић Венцловић Г. Факултет за правне https://doi.org/10.18485/ai_most.2017.ch12 и пословне студије др Лазар Вркатић, Нови Сад nadasavk@gmail.com

\title{
ВЕНЦЛОВИЋЕВА БЕСЕДА О НЕПРОХОДЉИВОМ МОСТУ СРПСКОГА ДРУШТВА
}

Невелика, мудра беседа из 1745. године Провалија између нас Гаврила Стефановића Венцловића сачувала је своју актуелност и данас, јер указује на подвојеност у српском друштву, на јаз између елите српског друштва и сиромашног и гладног народа. Упућена је шајкашима који 1741. нису ушли у нову граничарску организацију аустријског царства и који су стрепели од неизвесне будућности. Венцловић критикује племство и упозарава на барокно „коло среће“, тј. променљивост животних околности и лако нестајање привилегија и богатства.

Кључне речи: беседа, пропаст, провалија, „непроходљива ћуприја“, барокно „коло среће“

У трагању за суштином људског бића и његовог света, како видљивог тако и невидљивог, мудри Гаврил Стефановић Венцловић исписао је у првој половини XVIII века неке од насуптилнијих страница српске књижевности. Све што се о Гаврилу Стефановићу Венцловићу зна одиграло се између 1711. и 1747. године, напомиње Милорад Павић: „Те прве године изронио је из мрака раног XVIII 
века; оне друге године, на исти начин нестао је у тами времена. Тачније, његов живот протекао је омеђен сеобама Срба. Започео је у атмосфери велике сеобе под Арсенијем Чарнојевићем 1690, достигао зрелост у тренутку кад је дошло до сеобе Срба с турске на аустријску територију под Арсенијем Јовановићем Шакабентом 1737. године, а угасио се негде у немирима и великим променама на аустријској граници, које су довеле до исељавања Срба у Русију средином XVIII века." (1972: 7) Први писац српске књижевности о којем се добар глас ширио и пре његовог доласка у нову средину био је и изузетан беседник: „Ва ${ }^{1}$ лето 1739. дође јеромонах Гаврил Стефановић, славни проповедник из Сентандреје“, забележено је у летопису цркве у Коморану. (Витковић 1887: 271)

Као писац Венцловић је откривен тек у XIX столећу; до тада је сматран преписивачем црквене литературе. Но, крајем XIX века утврђено је да није само преписивао текстове, него да је на основу предлошка, односно неког извора, писао и литерарна дела. Гаврило Витковић уочава да је период његовог самосталног књижевног рада трајао од 1725. до 1745. године. (1872: 157) Тек радом историчара књижевности у XX столећу долази до заслужене афирмације његовог дела. Његов опус се може поделити у две групе: на литературу научног и теоријског карактера, на српскословенском језику, и на дела за шири круг слушалаца, за његову шајкашку паству: беседе, прозне и поетичне текстове на народном језику сремског краја. Беседе су настајале у складу с његовим веровањем у моћ живе речи; он је у беседничке оквире инкорпорирао и друге књижевне жанрове. Једини је писац тога периода који пише на два језика. Схватање „првог, а уједно и последњег“ нашег писца, који пише на два језика, о упо-

1 Гаврило Витковић пише $в a$, мада је било уобичајено да се пише: въ, во или в. 
треби двојезичности јесте чврста основа, по Ђорђу Трифуновићу, за изградњу „моста између старије и новије“ српске књижевности (1994: 50-51). Трифуновић, ипак, наглашава да је Венцловић углавном био преписивач, преводилац приређивач старијих књижевних извора, „а у скромнијим тек сразмерама може се говорити о њему као оригиналном писцу у савременом значењу те речи“ (1994: 78)“. Сходно сагледавању Венцловићевог опуса у духу барока, Милорад Павић уочава да се његова поетика заснивала на тежњи да буде непоновљив и непредвидив. Меша Селимовић наводи да је Венцловићева поезија изузетне лепоте, а он „један од најсуптилнијих песника које смо икада имали“ (1973: 111), којег су створили „дуга традиција славеносрпске школе и њен интерес за духовне теме, традиционална поезија невезаног слога, живе везе са савременом светском поезијом, и одлично познавање народног језика“. (1973: 112)

Од текстова на говорном, односно народном језику насталих између 1732. и 1746. године сачувано је девет хиљада страна: Поученија и слова разлика (1732), превод прва два тома проповеди Лазара Барановича, руског архиепископа, беседника и теолога Мач gуховни (1736), затим Житија. слова и йоуке (око 1740), Великойостиник (1741), Пентиикосиии (1743), Слова избрана (1743) и Поученије избраное у две књиге (1745. и 1746).

Јован Скерлић предочава да је имао „више црквеног образовања но иједан црквени човек међу Србима онога времена“ (1923: 169), као и да су његове беседе једне од најбољих у српској омилитици, јер их одликује чист и течан народни језик, права народна синтакса, богат речник, обрти и фигуре из народног причања. Он истиче да су Венцловићеве беседе „одраз стварног и велико познавање народног живота, разумеваљња народних потреба и озбиљног схватања пастирске дружности“. (Скерлић 1923: 171, 172) Јован Деретић напомиње да се Венцло- 
вић као ниједан писац пре њега спушта у конкретно, материјално, чулно, да се бави питањима и из живота обичних људи. (Деретић 2007: 423) Трудио се да буде разумљив својим необразованим слушаоцима, да им се обраћа језиком и стилом који им је близак. Но, с друге стране, код њега се уочавају и сасвим супротне тежње; узлети у спиритуално, метафизичко, тајанствено, описи природних појава, историјске и космичке визије, обиље песничких слика, метафора, емблематских и симболичких израза.

Венцловић у Похвали бесеgнику наглашава да је беседник баш онај који људе уразумљује, па зато његовом разуму нема краја, да је онај ко познаје тајне туђих срца и који књиге познаје, а да му је језик „кано перо скорписца књижевна“ мада не пише пером „него својим прстом без мастила“. (1966: 158) Исписао је и молитву за добру беседу у којој моли Бога да му у његова земљана уста пошаље реч која у кротости тече у уши његових слушалаца. (1966: 123) Није заборавио ни његове возљубљене слушаоце, у Молитиви за слушаоие моли Бога да они приме његове речи које му је Он дао. Његово беседничко умеће потрђује и невелика, а тако мудра беседа из 1745. године Провалија између нас, која је сачувала своју актуелност и данас. Актуелна, јер је подвојеност коју апострофира и данас изражена у нашем друштву.

\section{ПРОВАЛИЈА ИЗМЕБУ НАС}

\section{„Голема пропаст разсела се међу нама и вама!“}

Пропаст - то је голема, широка и сасма дубока провалија где но проходљива ћуприја ни од којих великих мудраца ни вештих мајстора наместити се не може. Јерно 
то овде тај мост свакоме преходљиви на вољи му стоји с повраћањем се са зла житка на бољи, с добра ли на гори. Ал' голема је у томе ето овде пропаст и сасма тврда. А како? У томе можемо се сами сећати и знати како јест нам то непроходљиво ни друг с другом смешато уједно.

Где би се велики бољари од воље му свега свога добра му, лепоношења и хузура пометнуо, те за просјака бос подносећи сваку тугу и невољу, претуцајући се по сокаци, подносио? Кад му није то за невољу трпити? Где ли пак љути и пуки голић, јоште болестљив, ако би и врло то желио и захтевао онако држати се и носити као неки бољарин, - ал' никако му не може то бити изарад сваке недоскутице.

Беседу Провалија између нас написана је највероватније у Коморану у којем је Венцловић боравио од $1734,{ }^{2}$ и где је 1743. довршио зборник Слова избрана на народном језику и где се, највероватније задржава све до 1746. године. Наиме, протоколи крштених и умрлих коморанске цркве вођени су до те године његовом руком. (Ковијанић 1953: 164-165) У Коморану се носио „са сиромаштвом и малобројношћу пастве, с Грцима који су непрестано подјаривали несугласице са српским парохијанима, с Мађарима који су вребали да премаме на унију његове житеље, са језуитима који му умало нису дошли главе, и са Србима који су, живећи у тешким приликама и сиромаштву, и сами устајали на њега, тужакали га и лишавали плате“. (Павић 1972: 20) Венцловић је 1732.

2 Ристо Ковијанић сматра да је протоколе својом руком водио Гарил Стефановић Венцловић од 1834. до 1846, јер је рукопис исти, те да је Венцловић у Коморану боравио од 1834, а не од 1839. године, тачније да је у том периоду „крстарио Дунавом од Сент-Андреје до Ђура, од Ђура до Коморана, и обратно, боравећи, служећи и проповедајући понекад у једном, понекад у другом, или трећем граду“ (1953: 164). Нпр. у запису 2677 из новембра 1736. године он се потписује као „капелан ђурски“. (Стојановић 1983: 105) 
записао да се време обрнуло, да су се људи изопачили и да су настале „године зле и опаке“. (1966: 304) Биле су то бремените године за наш народ у сваком погледу, само годину дана пре него што ће исписати поменуту беседу, дакле 1744. године, Срби су упутили жалбу Сабору у којој су предочили да се с њима поступа као с робовима! У његово време није било верске једнакости, његови Срби и православаци у аустријској царевини били су третирани као шизматици, зато је и наглашавао питање оданости и одбране народности, упозоравао је своје шајкаше да се не одричу свога рода. Добро је познавао своју паству и средину у којој је живео. Његове беседе су упечатљива и ретка слика нарави и морала свих сталежа. Често је у његовим шајкашким беседама указивао на неједнакост као извор неслоге међу Србима, сматрао је да је неслога извор сваке несреће у народу. Сметала му је изолованост нашег племства од сопственог народа и питао их је и упозоравао: „Тко те храни?“ (Венцловић 1966: 308) У проповедима често је жестоко критиковао српско друштво, био је оштар готово према свим друштвеним слојевима. Његови критички ставови су проистекли из уверења у моћ просвећивања, у значај школовања и неопходност књига, упозоравао је да је непросвећен народ угрожен у непријатељској средини која је супериорнија на културном плану.

Цицерон је сматрао да се песник рађа, а говорник постаје, а Венцловић је био и песник изузетног талента и умни, убедљив говорник који је вешто крчио пут својој речи до његове неписмене шајкашке пастве. У његово време Срби су због снажног верског и политичког притиска католичког окружења нарочито ценили беседништво. Реторика је указивала на списак врлина које су утицале на морални лик говорника, најважније су: честитост, добронамерност, скромност, пристојност, обазривост итд. Ништа од тога му није недостајало. 
Венцловић у беседи Провалија између нас указује на велику, широку и дубоку провалију између „нас и вас“ коју ни „проходљива ћуприја“ не може да премости. Велики јаз настао је између елите српког друштва: племства и богаташа, с једне стране, и сиромашног голог и гладног народа, с друге стране, и њега није могло да премости ни мудрост великих мудраца, ни вештина вештих мајстора. Посебно је ценио мудрост истицао је да је она „свему поглавица“, тј. да је најважнија, да у себи садржи свако добро, као и да је мудрост пут ка Богу. ${ }^{3}$ Мудрост је у основи и његовог сагледавање суштине Бога. Бог је, сматрао је како пише у књизи Пенйикоси (1743), јединство троструког моралног принципа, означио је овај принцип грчким термином енс или нашки $\delta и \bar{u} н о с \overline{\mathcal{u}}, е н с$ обухвата мудрост, истину и доброту. По истицању важности мудрости близак је Платону, који је сматрао да је мудрост једна од четири основне врлине, поред одважности или храбрости, умерености и праведности. Венцловић је у два наврата и поменуо Платона: када указује на необразованост свештенства и када се обраћа филозофима у полемици с католочким догматицима. Познавање античке књижевности и философије заузима „једно од средишних места“ у његовом образовању, (Павић 1965: 348) У књизи, Слова избрана (1743), Венцловић пише и о античкој драми и о митологији. Његове грчке студије веома су допринеле његовој ерудицији. Знао је грчки и латински, и по његовим делима расута су многобројна објашњења грчких речи. Као православни свештеник морао је да служи службу у црквама с мешовитом паством, и на српском и на грчком језику.

3 Мудрост је свему поглавица и свако добро у себи је зграштила (згабила) и присегла и самог Бога у себи има, ко је добро изучи, т ш њоме Бога стече. Ја шта већ на свету боље из тога имати иштеш?“ (Венцловић 1966: 489); „Ама мудри и добри, прави ако сте, то сте и благородни, недвообразни, частни с ходом и ношењем!“ (Венцловић 1966: 345) 
Као што је то често чинио, он, такође, у наведеној беседи указује и на барокно „коло среће“ и упозорава на „проходљиви мост“, дакле, на мост пролазности, односно на „повраћање“ од зла ка добру, од добра ка злу. Та провалија између нас, упозорава Венцловић, наша је пропаст која је потпуно постојана, како он каже „сасма тврда“. Пита се зашто је то тако, а у одговору указује на непостојање повезаности између једног слоја српског друштва са другим, на провалију у српском народу. Племић се никада не би вољно одрекао, како каже Венцловић „оставио по страни“, лепоношења и луксуза. Такође, ни пуки голаћ, ни због нужде, не би могао, чак и кад би то веома желио, да се држи и носи као племић. Једноставно, српска елита онда, као и данас, није била спремна да дели судбину сопственог народа. Напротив, то је био слој који је најчешће прихватао да се покатоличи не би ли напредовао у друштвеној хијерахији. Српско племство које је живело у Угарској пре 1690. године претежно је било нижег ранга и временом се помађарило, неки су помађарили своја презимена, понекад, не мењајући веру. Два пута је поменуо мост, први пут да истакне да се та провалије између две отуђене групе истог народа не може премостити, а други пут, опет метафорично, када указује на пролазност, на барокно „коло среће“. У беседи Коло среће он упозорава „данас срећан, честит и богат а сутрадан напала штета, притисла рђа и чађа и свака несрећа сколила“. (Венцловић 1966: 453)

Уочавао је изражену супротност и критиковао је изолованост племства од народа, зато се и обраћа српском племству, јер га је сматрао извором неједнакости у српском друштву. Гледао је припаднике племства у цркви за време проповеди и није му се допадало ни њихово држање, ни њихово помпезно одевање, по чему су се одвајали од шајкашке масе, као што му се нису допадали ни српски богаташи тог времена - занатлије, 
трговци, грађани, учитељи... Беседе исписане на народном језику сведоче о околностима у којима је Венцловић живео. Деловао је у времену антагонизама, када се диференцирају интереси српског свештенства и грађанства, када долази до успона трећег сталежа, а морао је да води рачуна и о утицају и значају официрског слоја, као и о положају сељака. Венцловић је био критичан и према свештенству, жигосао је њихово одрођавање од пастве, замерао им је да немају ауторитет у народу. По његовом мишљењу од племства је у првом реду зависило да ли ће односи у друштву бити правично регулисани. Само правични односи, по њему, омогућавали су безбедно и мирно управљање. Истицао је да правога племства „по крви“ нема, јер се благородност познаје једино по племенитим делима, као и да су личне вредности изнад привилегија племства. Често је упућивао критику племству и богаташима, упозаравајући их на барокно „коло среће“, тј. променљивост животних околности, односно лако нестајање привилегија и богатства. Указивао је на потребу да се помаже сабраћи, на помагање онима који живе у оскудици, апеловао је: „Јеси ли човек - човек и буди“. (Венцловић 1966: 309)

Поставља се питање зашто Венцловић апострофира племство, које је било малобројно, јер је 1715. године забележено је да је у Коморану било само пет племића официра Срба, не зна се колико је их је било у време настанка беседе, но сигурно не много више. Средином XVII и почетком XVIII века у Коморану су обитавале следеће српске племићке породице: Бељаковић, Будаји (раније Летић), Ваљи, Деметер, Дијак, Домонкош, Дузи, Естергоми, Ђенђеши, Зомборлија, Зупанић, Јеновац (касније Јенеји), Капелети, Капошвари, Киш, Ковач, Ленчиш, Пап, Пешти, Пожунлија, Рац, Станковић, Темешвари, Халас, Фаркаш (раније Вуковић), Фелдвари, Фехирвари, Фогаш, Чанади и друге. (Поповић 1939: 118) Посебно су 
биле угледне племићке породице Монастерли, Пешти, као и породица Бранковић која се успела на хијерархији до грофовске титуле. Нарочиту врсту племства у аустријском царству, која није имала посед, али је била материјално обезбеђена, чинили су и официри који су се истакли изузетним јунаштвом. Ниже племство није било ни политички, ни друштвено хомогена група, али се, ипак, издвајало од народа, чинећи део друштвене елите која је имала могућности, додуше ограничене, да утиче и на државну политику. У околностима када је народ лишен сопствене државе Венцловић се обраћа њиховим представницима, тј. друштвеној елити с очекивањем да искажу вољу да њеним залагањем утичу на државну политику у вези са положајем шајкаша. Његово интересовање за античку књижевност и античку мисао утицало је на овакво сагледавање улоге власти. Задатак власти je, по Платону, да ублажава разлике које већ природно постоје међу грађанима, како временом не би дошло до међусобног израбљивања и пропадања града (државе). Платон ${ }^{4}$ је указивао на пропаст и народа и државе ако је власт у рукама оних који гледају само сопствени интерес.

Беседа је изговорена и исписана у трећој, последњој фази Венцловићевог живота, која почиње четрдесетих година и траје до смрти. То је период када је стар и уморан, и када је своје беседе све чешће бележио онако како их је

4 „Ако за оне који су одређени да владају пронађеш неки начин живота који је бољи од владања, онда постоји могућност да се створи држава којом се добро управља. Само ће у њој владати заиста богати људи, и то не богати златом, него оним чиме мора бити богат срећан човек: добрим и разумним животом. Но ако до власти дођу они који у својој оскудици жуде за добрима која би била само њихова, убеђени да је управо власт оно место на којем се може највише награбити - тада ће та могућност ишчезнути. Тада ће доћи до борбе за власт, па ће ова - слично ономе што се догађа у рату - упропастити и њихова домаћинства и целу државу.“ (Платон 2002: 212) 
и говорио - чистим народним језиком. У запису 2853. из 1743 година за себе каже да је: худи ${ }^{5}$ списатељ у дубокој старости, а потписао се као ученик општега духовника Кипријана Рачанина. (Стојановић 1983: 138) У неколико наврата себе назива худим списатељем и потписује се као ученик Кирпијана Рачанина. Ђорђе Трифуновић запажа да у Венцловићевој појави има у некакве велике трагичности; и сам Венцловић је нагласио „доста сам се црна чемера нагутао и пун сам већ једа“. (1966: 294) У трећој фази његовог стваралаштва настао је и највећи број његових књига са беседама српским шајкашима.

Коморански шајкаши су 1739. године учествовали у борбама заједно с флотом великих бојних бродова, и поново су се нарочито истакли. Међутим, после битке 23. јула 1739. код Гроцке, и пораза Аустрије, граница према Турској била је померена на доњи Дунав и Саву, „које постају и остају дуго времена граничне реке између два царства“. Коморански, ђурски и острогонски шајкаши и њихова флотила нису више били потребни на горњем Дунаву, јер су се нашли далеко од нових граница. (Ћоровић 2006: IV/ 141) Аустријске власти су 1741. донеле закон да се ови шајкаши преместе на Тису, Саву и доњи Дунав. Они који нису пристајали на селидбу морали су да постану сељаци, а официрима се додељивало племство када су напуштали војничку службу. Шајкаши се први пут спомињу 1355 . године у повељи угарског краља Лајоша I Великог, у којој се бродарима званим „saytias“ додељује повластица у вези са ослобађањем од плаћања пореза. (Рокаи 2014: 12) Након битке код Мохача (1526) Коморан је постао главно место шајкаша. Ипак, упркос великим ратним заслугама, након вишевековног чувања

5 Худи = бедни, јадни, несрећени, кукавни. У записима 2623. и 2640. каже за себе да је убоги свештеник. Писао је да је некада био у таквој оскудици да није имао за другу ризу, односно одежду. 
границе, највећи део шајкаша није ушао у нову граничарску организацију аустријског царства, и Венцловић је последње године свог живота провео у кризном периоду за шајкаше, који су знали да се њиховим флотилама ближи крај и који су стрепели за будућност. Опхрвани осећањем неизвесности одлазили су на последње походе у Баварску, за време рата за аустријско наслеђе вођеног од 1740, када Марија Терезија долази на престо, до 1748. У тако тешким тренуцима Венцловић је очекивао да се, како пише у беседи, друг с другом помеша, односно да људи помажу једни другима, а не да гледа представнике народа, племство, које не хаје шта ће сутра бити са њиховом браћом. И отуда та Венцловићева горчина и крик о пропасти.

Један од главних представника нашег беседништва, Гаврил Стефановић Венцловић, начинио је значајан и успешан избор да у беседовању уместо црквенословенског језика, који је дотад био искључиви језик беседништва, користи народни језик. Беседе на народном језику истовремено су промовисале образац једног необичног стила, који је настао зближавањем двеју беседничких школа: западне, која је преко Пољске стизала у Русију, и источне, византијске, која се није ни гасила на овом тлу. „Осим византијско-словенске духовне књижевности и усмене, народне традиције, треба посебно истаћи утицај барокне омилитике каква је негована у руској и украјинској књижевности XVII века [...] За њега је карактеристично повезивање сакралног и профаног, духовног и телесног, небеског и земаљског“ (Деретић 2007: 426) Наше барокно беседништво користило је наслеђе старе српске књижевности, која је вековима била под утицајем византијске омилитике, и њеног најзначајнијег представника Јована Златоустог, као и савремену праксу барокног времена која је створена по одређеним правилима у украјинској књижевности. С друге стране, писање на народном језику слу- 
жило је и националном самоодржању. Питање језика за етничку заједницу која је живела у туђој држави било је и те како важно, јер је језик био један од најзначајнијих кохезионих елемената њеног идентитета. Народни језик је био у XVIII веку један од стубова патриотизма појединца, који је утемељен и на идеји о чврстој, националној повезаности људи која говори истим језиком.

Провалију је поменуо два века касније, такође, Иво Андрић у роману На Дрини ћуйрија у хоџиној причи о постанку моста, али ону коју је начинио ђаво, тј. шејтан, и која је раздвојила људе удаљивши их тако да нису могли да је премосте, него су се мучили развојени на две обале. Анђели су раширили крила над провалијама и помогли су људима да непремостиво премосте. Људи су од анђела, дакле, научили како се граде мостове, зато свака ћуприја и има свога анђела који је чува и држи „док јој је од Бога суђено да стоји“. (Андрић 1976: 258) Венцловић је писао о анђелима и сликао их је. Указивао на постојање великог света: света Бога „којино своје луче пушта од оца и сина и светога духа“, као и на „други свет, ангелски“. (1966: 165) Када је покушавао да објасни суштину анђеоских сила указао је на њихов морални принцип, на њихову окренутост ка доброти:

Ми баш право не можемо сазнати што су они, умови ли су - што велимо памет - душе ли, или ватра, или тек неко видело је ка муња што сева. Хеле, неосежна је ствар 6 , ни вићена нами. Нити им места има где кога тврда на што би се опирали и стајали би ил му седили - безтелесна је вешт? ! У једну орахову љуску сви би стали, а један опет толико из њих може голем бити ка једна висока планина и на зло су непокретни нити им то може бити [да] на које зло

6 Дакле, неопиљива је ствар. Речица хеле, пише се и у облику еле, а значи: дакле, било шта било, али тек; неосежан, значи неопипљив. Вешт $=$ ствар. 
они устају, него ли свакад су на добро и к бољем затичући се окретни. (цит. према Павић 1972: 150)

Наш „убоги свештеник“ нагласио је да само „у мудрој глави влада божији свет“. (Венцловић 1966: 165) Зато у његовој беседи нема анђела, мада би се можда и очекивао, нема га јер нема ни мудрости међу људима - тог, по њему, правог пута ка Богу.

\section{ИЗВОРИ И ЛИТЕРАТУРА}

Андрић, Иво. На Дрини ћуйрија. Београд, Загреб, Сарајево, Љубљана, Скопје: Просвета, Младост, Свјетлост, Државна заложба Словеније, Мисла, 1976.

Богдановић, Милица. „Девет писама Гаврил Стефановић Венцловића“. Зборник Майице срйске за книжевности и језик, IV-V (1958): 233-247.

Венцловић, Гаврил Стефановић. Црни биво у сриу. Београд: Просвета, 1966.

Витковић, Гаврило. „О књижевном раду јеромонаха Гаврила Стефановића“. Гласник Срӣскоі̄ ученоі друшйва, XXXIV (1872): 151-177.

Витковић, Гаврило. Прошлости устианова и сйоменищи уїарских кратевих шајкаша og 1000. gо 1872. ӣо срӣским и стираним изворима. Београд: Штампарија Краљевине Србије, 1887.

Деретић, Јован. Исйорија срӣске кюижевносиии. Зрњанин: Sezam Book 2007.

Ковијанић, Ристо. „О Гаврилу Стефановићу-Венцловићу“. 38орник Матиице сритске за книжевности и језик, I (1953): 164-165.

Скерлић, Јован. Истиорија срйске книжевностии у XVIII веку. Београд: Издавачка књижарница „Напредак“, 1923.

Платон. Држава. Београд: Београдско издавачки-графички завод, 2002.

Павић, Милорад. „Гаврил Стефановић Венцловић“. Книжевностй XL/4 (1965): 326-348. 


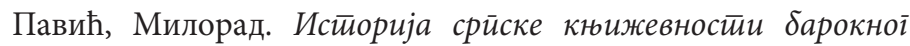
goбa: XVII и XVIII века. Београд: Нолит, 1970.

Павић, Милорад. Гаврил Сйебановић Вениловић. Београд: Српска књижевна задруга, 1972.

Душан Ј. Поповић. „Племство“. Војвоgина 2. Нови Сад: Историјско друштво, 1939, 111-137.

Рокаи, Петар. „Први помен шајкаша“. Шајкашка: йростиор - сииа-

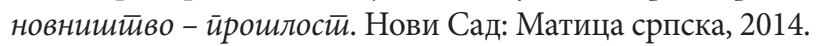

Селимовић, Меша. „Језик Гаврила Венцловића“. Og барока go класищизма. Милорад Павић (ур.) Београд: Нолит, 1973, 111-117.

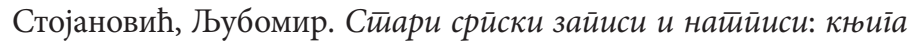
gруїа. Београд - Нови Сад: Српска академија наука и уметности - Народна библиотека Србије - Матица српска, 1983.

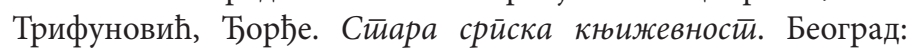
„Филип Вишњић“, 1994.

Ћоровић, Владимир. Илусиирована истиорија Србије: књиїа четиврий. Београд: Политика, 2006.

Nada Savković

\section{VENCLOVIĆ'S SPEECH ON \\ A NON-PASSABLE BRIDG OF SERBIAN SOCIETY}

\section{Summary}

Gavril Stefanović Venclović, one of the wisest writers of the Serbian literature of the eighteenth century, wrote in 1745 in the national language a small speech The Gulf Between Us, which has preserved its topicality today. Venclović writes about the ambivalence of the Serbian society, the chasm between the elite of the Serb society and the poor, barefoot and naked people. He believed that the discord among was the source of misfortune for a nation. His interest in ancient literature and ancient thought had an impact on the perception of the role of government and its 
responsibility, especially in circumstances where the people were deprived of their own state, when it is represented by its social elite. Plato pointed to the destruction of both the nation and the state when the power is in the hands of those who look only to their own interests. Criticising the nobility, Venclović points to the baroque "wheel of fortune", i.e., changeability of life circumstances and to the easy disappearance of privileges and wealth. The speech was given in Komoran, as he was addressing the Šajkaš people who in 1741 did not join a new frontier-defending organisation of the Austrian Empire, and who were afraid of their uncertain future. In such difficult moments Venclović expected from people to help each other, and not for the representatives of the people, the nobility and the rich, to be negligent about what tomorrow will bring to their brethren.

Key words: speech, disaster, gulf, "non-passable bridge", baroque "wheel of fortune" 